\title{
Factors Affecting Fertilizer Consumption in Rajasthan
}

\author{
Deepali Chadha" and G.L. Meena
}

Department of Agricultural Economics and Management, MPUAT, Udaipur- 313001, Rajasthan, India

"Corresponding author: deepalichadha6989@gmail.com (ORCID ID: 0000-0003-4135-811)

Received: $14-04-2019$

Revised: 16-07-2019

Accepted: 22-08-2019

\begin{abstract}
The present investigation was carried out to determine the factors affecting fertilizer consumption in Rajasthan from 1967-68 to 2014-15. The study period had been divided into following three phases; Post-green revolution- Phase I (1967-68 to 1980-81), Post-green revolution- Phase II (1981-82 to 1990-91) and Post-reform period (1991-92 to 2014-15).The regression analysis was done for the three temporal phases as well as for the overall period. High coefficient of multiple determination $\left(\mathrm{R}^{2}\right)$ indicated that 90 per cent of total variation in fertilizer consumption was explained by the variables included in the linear regression model. Gross irrigated area was found to be the most important variable influencing the fertilizer consumption during the three phases as well as for overall period of study. Its coefficient was found positive and statistically significant $(\mathrm{P}<0.05)$. Area under high yielding varieties appeared to be the second most important variable significantly influencing the fertilizer consumption. Its coefficient was found positive and statistically significant $(\mathrm{P}<0.05)$ during the overall study period. The regression coefficient of rainfall was found to be statistically non-significant in all the three temporal phases of study period. Although it was positive in phase I and negative in phase II and III.

\section{Highlights}

( Results clearly indicated that increase in area under irrigation and high yielding varieties will accelerate fertilizer consumption in the state in future.

( R Rainfall was found to have insignificant impact on fertilizer consumption indicating the erratic behaviour of monsoon in the state.

( On an average, one hectare increase in area under irrigation and area under high yielding varieties resulted in an increase of $150 \mathrm{~kg}$ and $43 \mathrm{Kg}$ in fertilizer consumption in the state respectively.
\end{abstract}

Keywords: Fertilizer, post-green revolution, regression coefficient, gross irrigated area, high yielding varieties

Chemical fertilizers are key element of modern technology and have played an important role in the growth of agricultural production in India. The role of the fertilizers in increasing the growth of agricultural sector, to meet the food-grain requirements of increasing population as well as increasing contribution to exports is clearly undeniable. Some argue that fertilizer was as important as seed in the Green Revolution (Tomich et al. 1995) contributing as much as $50 \%$ of the yield growth in Asia (Hopper 1993 and FAO 1998). Others have found that one - third of the cereal production worldwide is due to the use of fertilizer and related factors of production (Bumb, 1995).
With the limiting land and increasing population, the only option available today, is to promote intensive agriculture. This can be achieved either by the expansion of cultivable area or through improving the productivity of available land. The present cultivable land area is not likely to increase substantially in the near future; therefore, it is essential to increase productivity of individual crops and intensify cropping systems to meet future food needs (Nampoothiri and Balasimha, 1999) and the importance of fertilizers in intensification of production and increasing yield on limited arable land is clearly undeniable. 
Rajasthan is the largest state in terms of geographical area $\left(342,239 \mathrm{KM}^{2}\right)$ and occupied 10.41 per cent of land area of country. The state of Rajasthan shared about 12.06 per cent of total gross cropped area of country. However, fertilizer consumption in state is only $54.93 \mathrm{~kg}$ per hectare which is much lower than that the national average $(123.41 \mathrm{~kg}$ per hectare) during 2016-17. The total consumption of $(\mathrm{N}+\mathrm{P}+\mathrm{K})$ in Rajasthan was 1.35 million tonnes which accounts for only 5.08 per cent of total consumption of India during 2016-17. (Rajasthan Agricultural Statistics at a Glance, 2016-17). Rajasthan being geographically the largest state in the country has a varied topography where soils differ in quality depending on the organic matter present in them, their physical structure, local climatic variation, the crop rotation cycle that is followed, availability of moisture etc. The nutrient carrying capacity of soils varies not only within the district but also village to village and even farm to farm. Soils of the state have low microbial activities and poor soil organic carbon due to which more than $75 \%$ soils of the state are not in good health. Deficiencies of Nitrogen, Phosphorous, Sulphur, Zinc and Iron are quite common. Nitrogen was found deficient in all the districts. Phosphorous was also found deficient in all the districts except seven districts and potassium was found medium in 55 per cent of the districts and high in about 45 per cent of the districts in Rajasthan (Rajasthan Agricultural Statistics at a Glance, 2015-16). The total consumption of $(\mathrm{N}+\mathrm{P}+\mathrm{K})$ in Rajasthan was 1.35 million tonnes which accounts for only 5.20 per cent of total consumption of India during 2016-17 (Rajasthan Agricultural Statistics at a Glance, 2016-17).

Large number of factors (e.g., agro-ecology \& technology, institutional and infrastructure variables, demographics, price and economic factors) plays a significant role in shaping the fertilizer consumption patterns. Agro-ecology \& technology factors includes such as introduction of new technology, high yielding crop varieties, expanded irrigation, availability of credit, changing cropping pattern and rainfall influencing the fertilizers consumption over a period of time in different parts of the country. Designing appropriate policies and interventions to stimulate fertilizer demand and supply, calls for a good understanding of past trends and the relative importance of various factors that influence fertilizer use. In the past, various researchers have carried out studies on determining the factors influencing the fertilizer consumption in various parts of India. In Odisha, factors like irrigation, HYV seed, season, size of farm, credit, etc., tend to influence the level of fertilizer use in groundnut cultivation (Jena and Mitra, 1994). Fertilizer consumption in Western Maharashtra is influenced by certain regional factors relating to natural endowments like different types of soils, amount of participation, river basins etc, and sociological variations such as attitudes towards work and progress, spending habits, social restrictions, etc. (Singh and Belakha, 1999). The study conducted in Rajasthan during the period (1990-91 to 1999-2002) reported that both the variables viz., rainfall and gross irrigated area were found statistically significant and positive (Meena, 2002).

Thus, keeping in view the wide variations in the consumption level of fertilizer use among different districts of Rajasthan, the present study aimed to find out the factors responsible for variations in fertilizer consumption which must be justified in the light of agro-climatic variations in the state.

\section{MATERIALS AND METHODS}

The present study, entirely based on the secondary data has been conducted for the period 1967-68 to 2014-15. Under this, regression analysis was done for the following three temporal phases viz, Post-green revolution- Phase I (1967-68 to 1980-81), Post-green revolution- Phase II (1981-82 to 199091) and Post-reform period (1991-92 to 2014-15) as well as for the overall study period (1967-68 to 2014-15). For this purpose, year wise data on fertilizer consumption, gross irrigated area, annual rainfall and area under high yielding varieties have been collected from the year 1967-68 to 201415 for whole Rajasthan using various sources like Fertilizer Statistics of India (Fertilizer Association of India, New Delhi), Statistical Abstract of Rajasthan (Directorate of Economics \& Statistics, Rajasthan, Jaipur) and Rajasthan Agricultural Statistics at a Glance.

The factors influencing the fertilizer consumption in the state were assessed by using the following multiple regression model:

$$
Y=f(X 1, X 2, X 3)
$$


Where,

$$
\begin{aligned}
& Y=\text { Year wise fertilizer consumption (tonnes) } \\
& X 1=\text { Year wise annual rainfall (centimetres) } \\
& X 2=\text { Year wise gross irrigated area (hectares) } \\
& X 3=\text { Year wise area under High Yielding Variety } \\
& \text { of crops (hectares) }
\end{aligned}
$$

\section{Choice and specification of model}

The regression analysis requires specification of a particular functional form and its subsequent estimation. The choice for a specific functional form was made both on the basis of economic and statistical criteria. The economic criteria consisted of looking at the sign and size of the estimates of parameters while statistical criteria consisted of looking at the statistical significance of parameter estimates and coefficient of multiple determinations $\left(\mathrm{R}^{2}\right)$. In the present study, two alternative forms of production function, namely, Linear and CobbDouglas were tried to ascertain the relationship between the fertilizer consumption and various factors affecting it. Their functional forms are given as under,

Linear form: $Y=a+\sum_{i=1}^{n} b_{i} x_{i}+u$

Cobb-Douglas form: $Y=a \prod_{i=1}^{n} x_{i}^{b_{i}} e^{u}$ or

$$
\ln Y=\ln a+b_{i} \sum_{i=1}^{n} \ln x i+u
$$

Where,

$Y=$ Fertilizer consumption

$X i^{\prime}$ s $=$ Input variables, $i=1 \ldots . .3$

$a=$ Constant term

Finally, linear production function was found more appropriate to study the relationship between the fertilizer consumption and various factors (input variables) based on appropriate sign and statistical significance of parameters estimated accompanied by highest coefficient of multiple determination $\left(\mathrm{R}^{2}\right)$.

\section{RESULTS AND DISCUSSION}

As the study period had been divided into three phases, so linear production function for the respective study periods as well as for the overall study period have been estimated and tabulated below:

Table: Regression Coefficients of Fertilizer Consumption Function

\begin{tabular}{lll}
\hline Temporal phases & \multicolumn{1}{c}{ Regression equations } & $\mathbf{R}^{2}$ \\
\hline Phase I & $Y=71119.6+282.82 X_{1}+0.031^{*} X_{2}$ & 0.91 \\
1967-68 to 1980-81 & $+0.039^{*} X_{3}$ \\
& $(38403.74)(231.27)(0.015)(0.016)$ & \\
& $Y=664400-1141.36 X_{1}+0.183^{* *} X_{2}$ & 0.89 \\
Phase II & $+0.078 X_{3}$ \\
1981-82 to 1990-91 & $(135089.3)(751.90)(0.043)(0.044)$ & \\
& $Y=382603-55.086 X_{1}+0.115^{* *} X_{2}$ & 0.92 \\
Phase III & $+0.091^{* *} X_{3}$ \\
1991-92 to 2014-15 & $(104584.9)(1714.53)(0.028)(0.029)$ & \\
& $Y=442111+208.29 X_{1}+0.150^{* *} X_{2}$ & 0.90 \\
Overall & $+0.043^{*} X_{3}$ \\
1967-68 to2014-15 & $(56912.99)(838.84)(0.017)(0.021)$ & \\
\hline
\end{tabular}

*Significant at 5 per cent level of significance; **Significant at 1 per cent level of significance.

Figures in parentheses indicates standard error of respective inputs.

A close perusal of the table for the overall study period (1967-68 to 2014-15) revealed that the coefficient of multiple determination $\left(\mathrm{R}^{2}\right)$ was 0.90 which indicated that 90 per cent of total variation in fertilizer consumption was explained by the variables included in the linear regression model. A very high coefficient of determination was found between fertilizer inputs and yield outputs with regard to maize and wheat in Himachal Pradesh (Kher and Bhatt, 1990).

Further, the regression coefficient of rainfall was found to be statistically non-significant. This variable was found to have no impact on fertilizer consumption in Rajasthan over entire period of time. This could possibly be due to low rainfall coupled with erratic behaviour of monsoon in Rajasthan. However Nagaraj (1983), Jena and Mitra (1994), Kayarkanni (2000) and Meena (2002) have found contradictory results when similar study was conducted for the whole of India, Odisha, Tamil Nadu and Rajasthan respectively.

A further perusal of the table revealed that gross irrigated area appeared to be the most important variable influencing the fertilizer consumption in Rajasthan. Its coefficient was found positive and statistically significant $(\mathrm{P}<0.05)$. On an average, one hectare area increase under irrigation resulted in 
AESRA

an increase of $150 \mathrm{~kg}$ fertilizer in the state. Meena (2002), Bala et al. (2005), Jaga and Patel (2012) and Kumar and Akshu (2017) have also reported similar kind of results in their respective studies.

Area under high yielding varieties appeared to be the second most important variable significantly influencing the fertilizer consumption. Its coefficient was found positive and statistically significant $(\mathrm{P}<0.05)$. On an average, one hectare area increase under high yielding varieties resulted in $43 \mathrm{~kg}$ increase in fertilizer consumption in the state. Nagaraj (1983), Desai (1991), Raguram and Chowdary (1999) and Sharma and Thaker (2011) have also obtained similar kind of results in their respective works. The regression coefficient of rainfall was found to be statistically non-significant in all the three temporal phases of study period. Although it was positive in phase I and negative in phase II and III. The regression coefficient of gross irrigated area was found to be positive and statistically significant in all the three phases of study period. The regression coefficient of area under high yielding varieties was found to have positive and significant $(\mathrm{P}<0.05)$ impact on fertilizer consumption in phase-I and phase-III, while it was found positive and non-significant in phase-II. Thus, the results of this study clearly indicate that increase in area under irrigation and high yielding varieties will accelerate fertilizer consumption in the state in future which in turn will boost the agricultural production by many folds. In some other studies, factors like annual total income of the farmers, one year lagged price, short term credit and educational level were found to be responsible for fertilizer use in sugarcane and kharif paddy crops in South region of Gujarat (Makadia et al.).

\section{CONCLUSION}

Results of linear production function for the overall period of study (1967-68 to 2014-15) revealed that gross irrigated area was the most important variable and area under high yielding varieties was second important variable influencing the fertilizer consumption. Regression coefficient of rainfall was found to be statistically non-significant revealing the erratic and uneven distribution pattern of rainfall in the state. The regression coefficient of gross irrigated area was found to be positive and statistically significant in all the three phases of study period viz., phase-I (1967-68 to 1980-81), phase-II (1981-82 to 1990-91) and phase-III (1991-92 to 2014-15). Area under high yielding varieties was found to have positive and significant $(\mathrm{P}<0.05)$ impact on fertilizer consumption in phase-I and phase-III, while it was found positive and non-significant in phase-II. Rainfall was found to be statistically non-significant in all the three temporal phases of study period. Although it was positive in phase-I and negative in phase-II and phase-III.

\section{REFERENCES}

Bala, B., Sharma, N. and Sharma, R.K. 2005. Cost and return structure for the promising enterprise of off-season vegetables in Himachal Pradesh. Agricultural Economics Research Review, 24: 141-148.

Bumb, B. 1995. Global fertilizer perspective, 1980-2000: The Challenges in Structural Transformation. Technical Bulletin T-42. Muscle Shoals, AL: International Fertilizer Development Center.

Desai, G.M. 1991. Issues and themes in growth of fertilizer use in India. Indian Society of Agricultural Statistics, 43: 81-102.

FAO. 1998. Guide to efficient plant nutrition management. FAO/AGL Publication, FAO, Rome.

Hopper, W. 1993. Indian agriculture and fertilizer: An outsider's observations. Keynote address to the FAI seminar on emerging scenario in fertilizer and agriculture: Global dimensions. The Fertilizer Association of India, New Delhi.

Jaga, P.K. and Patel, Y. 2012. An overview of fertilizers consumption in India: Determinants and outlook for 2020A review. International Journal of Scientific Engineering and Technology, 1: 285-291.

Jena, S. and Mitra, A.K. 1994. Fertilizer use in groundnut cultivation in Orissa: An analysis of the associated factors. Agricultural Situation in India, 48: 873-883.

Kayarkanni, S. 2000. Fertilizer demand in Tamil Nadu: A macro analysis. Agricultural Situation in India, 5: 29-32.

Kher, D. and Bhat, G.M. 1990. Economics of fertilization in maize and wheat: A study of Himachal Pradesh. Agricultural Situation in India, 45: 24.3-24.7.

Kumar, S. and Akshu. 2017. Growth and pattern of fertilizer consumption in Haryana. International Journal of Research in Economics and Social Sciences, 7: 138-148.

Makadia, J.J., Mistry, H.H. and Kuthe, S.B. 2015. Impact of soil health card on determinants of fertilizer consumption and fertilizer use efficiency in Gujarat, India. Economic Affairs, 60(4): 577-583.

Meena, D.P. 2002. Spatial and temporal analysis of fertilizer use in Rajasthan. Thesis, Submitted to MPAUT, Udaipur.

Mohanam, T.C. 1990. Determinants of fertilizer use in Tamil Nadu. Agricultural Situation in India, 45: 387 - 395.

Nagaraj, R. 1983. Determinants of fertilizer use in Indian agriculture. Economic and Political Weekly, 18(13): A2-A15. 
Nampoothiri, K.V.K and Balasimha, D. 1999. Area and cocoa - Viable alternative. The Hindu - Survey of Indian Agriculture, pp. 97 - 99.

Raguram, P. and Chowdry, K.R. 1999. Factors influencing fertilizer consumption in Andhra Pradesh- A micro-macro analysis. Agricultural Situation in India, 40: 735-737.

Sharma, V.P. and Thaker, H. 2011. Demand for fertilizers in India: Determinants and outlook for 2020. Indian Journal of Agricultural Economics, 66: 638-661.
Singh, J. 2013. Demand projection of chemical fertilizer's consumption in India: Determinants and outlook for 2020. International Journal of Transformations in Business Management, 2: 62-76.

Singh, S.P. and Belaka, J.B. 1999. Factors affecting fertilizer consumption in the western Maharashtra. Agricultural Situation in India, 56: 361-363.

Tomich, T., Kilby, P. and Johnson, B. 1995. Transforming agrarian economies: Opportunities seized, Opportunities missed. Cornell University Press, Ithaca, New York. 
